\title{
PROGRAMÉRTÉKELÉS A 2000. ÉVI MAGYARORSZÁG-AUSZTRIA PHARE CBC KISPROJEKT ALAP PÉLDÁJÁN
}

\author{
(Program Evaluation - Case of Hungary-Austria Phare CBC \\ Small Project Fund 2000)
}

\section{LADOS MIHÁLY}

Kulcsszavak:

határ menti együttmüködés programértékelés

A magyar-osztrák határtérségben a hatär menti kapcsolatok fejlödését nagymértékben segíti, hogy az Európai Unió kiemelten foglakozik határ menti térségek, mint jellemzöen elmaradott térségek támogatásával. A tagországokon belül Interreg, míg az EU-határok mentén a nem tagországok számára a Phare $C B C$ program támogatja a határon átnyúló kezdeményezések megvalósitását. A kapcsolatok sürüsödése, mélységének és sokszinüségének növekedése az egymásmellettiségtỏl az integrált régió irányába mozdíthatja el az államhatárokkal elválasztott térségeket. A program Unión beliali sikeres megítélését jelzi, hogy a 2007-2013-as program idöszakban a megszünö Közösségi Kezdeményezések szintjéröl a Strukturális Alapok célterületei közé kerülnek a hatâr menti együttmüködések. Szükséges annak áttekintése, hogy az egyes programok mennyiben segitik az integrálódás folyamatát. Jelen tanulmány a 2000. évi Magyarország-Ausztria Phare CBC Kisprojekt Alap ex-post tipusú értékelésével kiséreli megragadni ezt a folyamatot. Az elemzési keretet a program és projekt szintü relevancia, koherencia, hatékonyság, hatásosság és fenntarthatóság vizsgálat adja. A tanulmány kiemelt figyelmet fordit a projektek keretében megvalósuló határon átnyúló partnerségre.

Az MTA Regionális Kutatások Központja Nyugat-magyarországi Tudományos Intézete „A határmentiségtől az integrált határrégióig” címü kutatás keretében a társadalmi és gazdasági élet számos területén vizsgálja a magyar-osztrák határ menti kapcsolatok evolúcióját az elmúlt másfél-két évtizedre visszatekintve. A nyolcvanas évek közepétől a határok nyitottabbá válásával a korábbi természetes kapcsolatok az élet minden területén újraéledtek.

A kapcsolatok erősödését, új együttmüködési rendszerek kialakítását segítette Ausztria EU-csatlakozásával a Magyarország nyugati határszakaszára megnyíló Interreg-Phare CBC program. A magyar fél - Györ-Moson-Sopron, Vas és Zala megye pályázati kedvezményezettjei - számára évente meghirdetésre került program nagyobb és kisebb projektek megvalósítását egyaránt támogatta. A közvetlen, helyi közösségek és szervezetek közötti kapcsolatok alakulásában a Phare CBC Kisprojekt Alap kiemelkedö szereppel bír. A nagy, jelentős forrást lekötỏ projektek területileg nagyobb térségekre fejtik ki hatásukat, ugyanakkor csekély partnerséget generálnak, illetve a partnerség jellemzỏen a magasabb politikai és igazgatási szintek között múködik. A kisprojektek azonban nagy számuk és változatos tartalmuk miatt sokkal inkább segítik a kapcsolatrendszer bővülését, sokszínüségét. 
A 2000-2006 közötti európai uniós programidőszakban ez a folyamat még erőteljesebbé válhat, hiszen a Phare $\mathrm{CBC}$ Kisprojekt Alap pályázatok alapvető kiválasztási szempontjai közé emelkedett a határ túloldalán lévő partner bevonása a projektbe. Ez a korábbi partnerségi nyilatkozatot aláíró kapcsolatról a valódi partnerség szintjére emelheti a projektek fejlesztésén és megvalósításán keresztul létrejövő együttmúködéseket. Ennek tesztelésére a 2000. évi Magyarország-Ausztria Phare CBC Kisprojekt Alap kínálkozik megfelelö esettanulmányként.

\section{Célok, a feldolgozás módszere}

Az esettanulmány általános célja az Ausztria-Magyarország Interreg IIIA - Phare CBC 2000-2006 program közbenső értékelése, a 2000. évi Magyar-Osztrák HU001503 Phare CBC Kisprojekt Alap megvalósulásának program és projekt szintủ elemzésén keresztül (ex-post értékelés). A közvetlen feldolgozást végző Budapesti Müszaki és Gazdaságtudományi Egyetem Területfejlesztési Kutatási Központ (BMGE TKK) és a megbízó VÁTI Kht. Nyugat-dunántúli Képviselete úttörỏ szerepre vállalkozott, hiszen ez volt az első ilyen jellegü munka Magyarország európai uniós támogatásainak felhasználása során.

A 2000. évi Kisprojekt Alapot értékelő tanulmány közvetlen célja annak vizsgálata, hogy a program céljainak érdekében mozgósított inputokkal (pénz, humánerőforrás, kapacitásépítés, képzés) megvalósultak-e annak tervezett kimenetei, eredményei, hatékonyan kerültek-e ezek az eszközök felhasználásra, és a célok, eredmények elérése érdekében történt lépések hatásosak voltak-e. Az EU-ban használt értékelési módszerek (ex-ante, közbensö, ex-post) egy egységes szempontrendszer mentén vizsgálják az adott programot. Ezek fóbb elemei a relevancia, a koherencia, a hatékonyság, a hatásosság és a fenntarthatóság.

A relevancia vizsgálata arra keresi a választ, hogy a Kisprojekt Alap célkitüzései mennyire válaszoltak a határrégió igényeire, hogyan illeszkednek a tágabb támogatási környezet célrendszerébe.

A Kisprojekt Alap koherenciáját vizsgálva a program egyes elemeinek (kimenet eredmény, cél, hatâs) összhangjára, egymásra épülésére kell kitérni.

A program hatékonyságának mérésénél az alábbi kérdésekre keressük a választ:

- Teljesült-e a legkisebb költség elve?

- Azonos költség mellett el lehetett-e volna érni egy jobb eredményt?

Kitértùnk arra, hogy a programvégrehajtó menedzsment müködése mennyire segítette a program hatásosságát, azaz hogy a pályázat meghirdetése, külső kommunikációja mennyire volt hatásos, illetve, hogy milyen képzést, tájékoztatást, ismertetőt kaptak a kedvezményezettek, ezeknek mi volt a program hatásosságát fokozó ereje. A hatásosság témakörénél vizsgáltuk, hogy a program outputjai, eredményei menynyire szolgálják a Kisprojekt Alap céljainak elérését.

Lényeges elemzési szempont a fenntarthatóság vizsgálata: a szervezet életében milyen változást hozott a projekt megvalósítása, mennyire rendelkeznek humán és pénzügyi kapacitással a projekt outputjainak müködtetésére, újbóli megismétlésére. 
A vizsgálatok a fenti kereteken belül projekt szinten kitértek a partnerkapcsolatok értékelésére is: a projektgazdák milyen szinten vonták be a projekt megvalósításába a külföldi partnert, illetve hogyan tervezik a partnerkapcsolat további alakulását.

Az elemzések a 2000. évi Kisprojekt Alaphoz kapcsolható (programdokumentumok, projektleírások, elemzések, pályázati felhívások stb.), illetve a pályáztatás és a programvégrehajtás során keletkező (logikai keretmátrix, projekt-zárójelentések) dokumentumok, valamint a programértékelést végző BMGE TKK által készített elsődleges adatfelvételek (programmenedzsment fókuszcsoportos és személyes interjúi, projektgazdáktól személyesen lekérdezett kérdőívek) feldolgozására támaszkodnak.

\section{Elözmények}

Kelet-Közép-Európa államaiban a rendszerváltásokat követỏ demokratizálódási folyamatokkal, a határok nyitottabbá válásával és a „Vasfüggöny” megszủnésével gyors fejlödésnek indultak a határ menti együttmüködések. Ezen országok integrációs folyamatának felgyorsulásával lényeges kérdéssé vált a tagjelölt országok és a tagországok közös határvidékén tapasztalható jelentős gazdasági különbségek feloldása, és a köztük lévő együttmúködések dinamizálása.

Az Európai Unió külső határaihoz kapcsolódó térségek felzárkóztatására indította el az Európa Tanács 1994-ben a csatlakozásra váró országok EU-határterületein a - Nemzeti Phare-programnak részét nem képező - Phare CBC (Cross-BorderCooperation) programot. A Phare CBC program célterülete az érintett országok NUTS III szintủ területi egységei. Ausztria 1994. évi EU-taggá válásával elsőként az osztrák-magyar határszakasz megyéi kerülhettek be a programba: a közvetlenül uniós határon elhelyezkedő Győr-Moson-Sopron és Vas megye, valamint a magyarosztrák-szlovén hármashatár térség részeként Zala megye. Így az 1995-1999-es időszakot átfogó Magyarország-Ausztria Phare CBC Indikativ Program kedvezményezettjei az említett három megye területén müködỏ szervezetek lettek.

A program öt prioritás fejlesztésére koncentrált, melyek a következők:

1) regionális tervezés,

2) müszaki infrastruktúrafejlesztés,

3) gazdaság- és turisztikafejlesztés,

4) humánerőforrás-fejlesztés,

5) környezet- és természetvédelem.

Az 1995-ben induló program eddigi története során - az 1998-as évet kivéve, amikor nem volt pályázati alap - a magyar-osztrák határszakaszon minden évben biztosítottak pályázati keretet, összesen 42 millió euró értékben. A program a 2000-2006 közötti új programidöszakban Ausztria-Magyarország Interreg IIIA - Phare CBC programként folytatódott, megtartva az elózó programidőszak prioritásait. A programidőszakon belül évi 10 millió eurós keret felhasználásával számolhattak a potenciális kedvezményezettek. Mindkét időszakot tekintve az egyes években, egyfajta forráskoncentrációt biztosítva, más-más prioritásokra esett a támogatások súlypontja. 
1995-ben a turizmus, a közlekedésfejlesztés és a gazdaságfejlesztés mellett a természet- és környezetvédelmi, valamint a humánerőforrás-fejlesztési projektek támogatottsága volt a legmagasabb. 1996-ban a humáneröforrás és turizmus projektek száma dominált, de a keretösszegböl nagyjából egyformán részesedett a gazdaság-, a közlekedés-, a természet- és környezetvédelem, a turizmus és a vízgazdálkodásinfrastruktúra fejlesztése. 1997-ben a gazdaságfejlesztési projektek részesülhettek a legnagyobb arányú támogatásban, 1999-ben viszont a forrás legnagyobb részét ismét közlekedésfejlesztésre fordították.

$\mathrm{Az}$ eddigi Phare $\mathrm{CBC}$ programok keretében darabszámban a humáneröforrásfejlesztés és a turizmus típusú projektek nyertek legtöbben támogatást. Jelentős különbség tapasztalható a nagy-és kisprojektek arányában. Előbbiek között legnagyobb számban a gazdaságfejlesztési és a közlekedés-fejlesztési (föként településelkerülö és megközelítő utak) projektek szerepeltek. Ezzel szemben - a projektek számarányát meghatározó - kisprojektek esetében a humánerőforrás-fejlesztés (nyári egyetemek, konferenciák, képzések) és turizmus típusú (rendezvények, kiadványok) projektek domináltak.

A támogatás összegét tekintve legnagyobb arányú támogatásban - magas költségvonzatuk miatt - a közlekedésfejlesztési projektek részesültek, míg a kisprojektek között a számuk szerint is meghatározó humánerőforrás-fejlesztés típusú projektek támogatása volt a legszámottevőbb. Legkisebb volt a ráfordítás a regionális fejlesztés és tervezés típusú projektek esetében (térségfejlesztési stratégiák, területfejlesztési programok), noha legalacsonyabb számban az egyéb infrastruktúrafejlesztési projektek szerepeltek.

A Phare $\mathrm{CBC}$, a határ menti együttmüködési programok keretén belül elkülönített speciális támogatási forma a Kisprojekt Alap, amely elsősorban a kisméretủ helyi és közösségi kezdeményezések felkarolására és támogatására szolgál.

\section{A Kisprojekt Alapról}

A Phare CBC Kisprojekt Alap (Small Projects Fund) átfogó célja az integrációs folyamat elősegítése a határtérség helyi szereplöinek bevonásával, fenntartható együttmüködési hálózatok kiépítésének ösztönzése és elősegítése, a helyi és regionális szereplők projektmenedzsment kapacitásainak és képességeinek fejlesztése.

A Kisprojekt Alap kulcsfeladatai - összhangban a Közös Programozási Dokumentummal és a 2760/1998 számú Bizottsági Rendelettel - a következők:

- A határ menti régióban helyi és regionális szereplök között fenntartható együttmüködési hálózatok kialakitásának ösztönzése és támogatása;

- A helyi szervezetek támogatása a határ menti régió projektjeinek kifejlesztéséhez és megvalósításához szükséges képességek és kapacitások fejlesztése terén;

- Közös projektmegvalósítási struktúra kidolgozása a történelmileg és kulturálisan különbözö régiók egyesitésével. ${ }^{2}$ 
Ezeknek a céloknak az eléréséhez a Kisprojekt Alap egy rugalmasabb támogatási rendszer kidolgozásával járult hozzá. Az 1995-1999-es programozási periódusban a Phare CBC programokon belül a Kisprojekt Alap volt az egyetlen támogatási eszköz, amelynek végrehajtása decentralizáltan, helyi szinten müködött. A programmenedzsment feladatokat ez esetben a Phare CBC Soproni Irodája látta el, míg a projektek megvalósítását közvetlenül a kedvezményezettek végezték. A nagyprojektek esetében a programmenedzsment a Phare CBC Programiroda központjában valósult meg, míg a projektmenedzsment egy EU-tagországban müködő keretszerződő szervezeten keresztül múködött. ${ }^{3}$

Egy projekt esetében az igényelhető támogatás minimálisan 1000 euró, maximálisan pedig 10 ezer euró volt az 1995-ös és 1996-os programévekben. Ezt követően a támogatás maximális összege 50 ezer euróra emelkedett (vagyis 1000 és 50 ezer euróra pályázhattak az 1997-es és 1999-es program keretében a jogosult szervezetek). Az 50 ezer eurós összeg nem csupán pénzügyi-támogatási határt jelentett, hanem a végrehajtás és a megvalósítás eljárásrendjében is határköként müködött.

A 2000-től indult új programidőszakban általános szabályként 50 ezer euróban határozták meg a Kisprojekt Alap maximális támogatási mértékét. A programmenedzsment feladatait a VÁTI Területfejlesztési Igazgatóság Nyugat-dunántúli Regionális Képviselete látja el. ${ }^{4}$

\section{A 2000. évi Magyarország-Ausztria Phare CBC Kisprojekt Alap általános jellemzöi}

A 2000-től indult új Phare CBC programidőszakban a Kisprojekt Alap keretében a jogosult földrajzi területet Ausztriában és Magyarországon a következő határ menti régiók alkotják:

- Győr-Moson-Sopron, Vas és Zala megyék a magyar oldalon

- Burgenland és Bécs tartományok, valamint a csatlakozó NUTS III régiók Alsó-Ausztriában: Niederösterreich Süd és Wien Umland-Süd

A 2000. évi Magyarország-Ausztria Phare CBC Kisprojekt Alap szerves folytatása az 1995-1999 közötti Magyarország-Ausztria Interreg IIA - Phare CBC programnak. A 2000-2006 közötti Magyarország-Ausztria Interreg IIIA - Phare CBC program nyitó évi keretének felhasználására meghirdetett Kisprojekt Alap a korábbiakhoz képest nagyságrendjét tekintve jelentősen megváltozott. A hét évet átfogó programozási dokumentum prioritásaival összhangban, döntően a határon átnyúló közvetlen emberi kapcsolatokat támogató program felhasználható forrásait és lehetséges tevékenységeit tekintve lényegesen meghaladta a korábbi kisprojekt alapok lehetőségeit. Egyrészt a pályázható keret nagysága hétszeresére, másrészt az egyes projektek maximális támogatási kerete hatszorosára növekedett.

Az 1995-1999-es programidőszakban a Kisprojekt Alap kerete 285 és 500 ezer euró között változott. A 2000-2006-os időszak közös programozási dokumentuma lényegesen többet, az éves keret $20 \%$-át, évi 2 millió eurót szánt a határ menti szervezetek 
Lados Mihály: Programértékelés a 2000. évi Magyarország-Ausztria Phare CBC

Kisprojekt Alap példáján. - Tér és Társadalom, 19. 2005. 2. 101-126. p.

106 Lados Mihály

TÉT XIX. évf. 2005 ם 2

közvetlen együttmüködését segítő akciókra 2000 és 2002 között. A pályázati kiírások eddig minden évben ennél kisebb összegre vonatkoztak (1. táblázat).

\section{TÁBLÁZAT}

A Magyarország-Ausztria Phare CBC Program Kisprojekt Alap jellemzói, 1995-2002

(Characteristics of Hungary-Austria Phare CBC Programme Small Project Fund, 1995-2002)

\begin{tabular}{|c|c|c|c|c|c|c|c|c|}
\hline \multicolumn{3}{|c|}{ Program } & Phare & Szerzödés- & Felhasznált & \multirow{3}{*}{$\begin{array}{c}\text { Fel- } \\
\text { haszná- } \\
\text { lás } \\
\text { aránya } \\
(\%)\end{array}$} & \multirow{2}{*}{\multicolumn{2}{|c|}{$\begin{array}{c}\text { Projektek } \\
\text { száma }\end{array}$}} \\
\hline \multirow{3}{*}{$\begin{array}{l}\begin{array}{c}\text { megneve- } \\
\text { zése }\end{array} \\
\text { HU9502- } \\
06\end{array}$} & \multirow{3}{*}{$\begin{array}{c}\text { kibocsá- } \\
\text { tása }\end{array}$} & \multirow{3}{*}{$\begin{array}{c}\begin{array}{c}\text { befeje- } \\
\text { zése }\end{array} \\
1999\end{array}$} & & & & & & \\
\hline & & & \multicolumn{3}{|c|}{ keret (ezer EUR) } & & (a) & (b) \\
\hline & & & 360,0 & 363,755 & 313,605 & 87,1 & 165 & 53 \\
\hline $\begin{array}{l}\text { HU9610- } \\
06\end{array}$ & 1998 & 1999 & 285,1 & 285,000 & 260,858 & 91,5 & 185 & 45 \\
\hline $\begin{array}{l}\text { HU9701- } \\
06\end{array}$ & 1999 & 2000 & 300,0 & 300,000 & 274,069 & 91,4 & 215 & 46 \\
\hline $\begin{array}{l}\text { HU9913- } \\
03-01\end{array}$ & 2000 & 2002 & 500,0 & 500,000 & 461,032 & 92,2 & 143 & 39 \\
\hline $\begin{array}{l}\text { HU0015- } \\
03\end{array}$ & $2001 / 12$ & $2003 / 12$ & $3.500,0^{1}$ & $3.353,458^{2}$ & $2.440,501^{3}$ & 70,2 & 98 & $36^{2}$ \\
\hline $\begin{array}{l}\text { HU0108- } \\
03\end{array}$ & $2003 / 03$ & $2004 / 11$ & 930,0 & 924,518 &.. & .. & 53 & 24 \\
\hline $\begin{array}{l}2002 / 000- \\
317-03\end{array}$ & $2004 / 04$ & $2005 / 11$ & $1.263,0$ & 914,898 & .. & .. & .. & 32 \\
\hline $\begin{array}{l}\text { 2003/004- } \\
575-03\end{array}$ & $2005 / 03$ & $2006 / 11$ & $1.000,0$ & .. & .. & .. & & \\
\hline Összesen & & & $8.138,1$ & $6.641,629$ & $3.750,065$ & $84,4^{4}$ & 859 & 275 \\
\hline
\end{tabular}

(a) Beadott pályázatok száma; (b) Szerződött projektek száma

'A pályázati felhívás 1.860 ezer eurós keretösszeget tartalmazott. A nagyprojekteknél felszabaduló források reallokációjával a keretösszeg 3.500 ezer euróra emelkedett.

${ }^{2}$ A Phare CBC támogatás eredeti szerződési értéke 3.417 .929 euró volt, amely 37 projekt között oszlott meg. Felsöcsatár Község Önkormányzata visszalépett a "Határon átnyúló vashegyi utak múszaki terveinek elkészittése" c. projekt megvalósításától. Ezáltal 64.471 euróval csökkent a szerzödéssel lekötött keret.

${ }^{3}$ Három projekt elszámolása még nem fejeződött be, ezek Phare támogatás tartalma 772.825 euró.

${ }^{4}$ Csak a már befejeződött programok keretösszegéhez viszonyítva.

Forrás: VÁTI TFI jelentések, VÁTI TFI Nyugat-dunántúli Regionális Képviselet.

A 2000. évi Kisprojekt Alap rendhagyónak tekinthetö, mivel a támogatás felső határa jelentösen meghaladja az általonosan alkalmazott 50 ezer eurós mértéket. A 300 ezer eurós támogatási határ már egyfajta átmenetet, kísérletet biztosíthatott a nagy ( 2 millió eurót meghaladó) projektek helyébe lépő, és az Interreg programhoz közelebb álló ún. „Támogatási konstrukciơ” (Grant Scheme) típusú támogatási rend- 
szerhez. Szintén eltért a kiírás a szokásostól abban, hogy a kedvezményezettek számára lehetőség nyîlt kisléptékü épitési beruházások megvalósítására is. Ez a regionális végrehajtási menedzsment számára is jelentös kihívást jelentett, hiszen az ekkora léptékủ projektek kezelését eddig a szervezet központjában, Budapesten látták el.

A 2000. évi Kisprojekt Alap pályázati felhívása 2001. december közepén jelent meg, 2002. február 28. 16 órai beadási határidővel. A megadott határidőre 98 pályázat érkezett be a soproni Képviseletre (2. táblázat). Hat pályázó a határidö lejárta után nyújtotta be anyagát, amelyek már nem kerülhettek értékelésre. Az alapvető megfelelőségi vizsgálatok és a hiánypótlást követóen 73 pályázatot értékelt 2-2 független szakértö. Az általuk készített értékelések alapján az Értékelö Bizottság két körben 37 projekt támogatását hagyta jóvá 3418 ezer euró értékben. Ez a rendelkezésre álló keret $97,8 \%$-át kötötte le.

\section{TÁBLÁZAT}

A 2000. évi Magyarország-Ausztria Phare CBC Kisprojekt Alap programkiírásra beérkezett pályázatok megoszlása (formailag megfelelt pályázatok) ${ }^{6}$ (Distribution of Incoming Applications for Hungary-Austria Phare CBC Programme Small Project Fund in 2000 (Formally Acceptable Applications)

\begin{tabular}{llccc}
\hline & & I. keret & II. keret & Összesen \\
\hline Támogatott & pályázati keretösszegböl & 13 & 7 & 20 \\
projektek & reallokált keretösszegböl & 12 & 5 & 17 \\
\hline Támogatott projektek összesen & 25 & 12 & 37 \\
\hline Nem támogatott projektek & 19 & 17 & 36 \\
\hline \multicolumn{2}{l}{ Mindösszesen } & 44 & 29 & 73 \\
\hline
\end{tabular}

Forrás: VÁTI TFI Nyugat-dunántúli Regionális Képviselet.

A támogatási döntést az EU Bizottság Magyarországi Delegációja 2002. augusztusban hagyta jóvá. A kedvezményezettekkel a Szerződő Hatóság 2002. szeptember-november folyamán kötött szerződést. A folyamat időbeni elhúzódása a pályázatban kiírt 18 hónapos futamidőt 10-12 hónapra szükítette, amely az építési komponenst tartalmazó projektek esetében veszélyeztette azok időbeni megvalósítását. A „második körben” jóváhagyott projektekkel 2003. januárban szerződtek. Számukra mindössze 8-9 hónap maradt a megvalósításra.

A támogatott projektek megoszlása a programban meghirdetett intézkedési területek között igen egyenlötlen (1.ábra). A 36 projekt több mint fele (58\%-a) a gazdaságfejlesztési intézkedési területhez tartozott. Ez tovább növeli ennek az intézkedésnek a dominanciáját, mivel az elöző programidőszakban a projektek $44 \%$-a tartozott gazdaság- és turizmusfejlesztés témakörébe. A következő legfontosabb intézkedést, az emberi eröforrás-fejlesztést a projektek további $28 \%$-a célozta (az elöző időszakban $33 \%$ volt az aránya). Így a további két prioritási szektorra viszonylag kevés projekt jutott, részarányuk az összes támogatott projektben mérséklődött az előző programidőszakhoz képest: a környezet- és természetvédelem 13-ról 8\%-ra, a regionális tervezés és fejlesztés 8-ról 6\%-ra. 
Lados Mihály: Programértékelés a 2000. évi Magyarország-Ausztria Phare CBC

Kisprojekt Alap példáján. - Tér és Társadalom, 19. 2005. 2. 101-126. p.

\title{
1. ÁBRA
}

A projektek megoszlása intézkedési területek szerint (Distribution of Projects According to Measuring Fields)

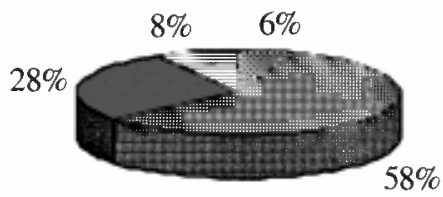

\author{
圆 1. Regionális tervezés és fejlesztés \\ 2. Gazdaságfejles ztés (és turizmus) \\ 3. Emberi eröforrás ok fejlesztése \\ 4. Környezet- és termés zetvédelem
}

Forrás: VÁTI TFI Nyugat-dunántúli Regionális Képviselet.

A kedvezményezett szervezetek típusuk, jogi státuszuk tekintetében az alábbi csoportokba oszthatók (2. ábra): gazdaságfejlesztési, valamint egyéb civil szervezetek az összes gesztor felét teszik ki (összesen 18 projekt). A második legnagyobb számban megjelenö csoport az önkormányzatok és társulásaik (összesen 10 projekt). Emellett fontos pályázói kört jelentenek még az oktatási-kutatási intézmények, valamint a dekoncentrált állami szervek (4-4 projekt). Az elöző programidőszakkal összevetve felére esett vissza az önkormányzatok aránya a projektgazdák között, de kismértékben ( 3 százalékponttal) mérséklődött az önkormányzati térségfejlesztési társulások súlya is. Ugyanakkor $20 \%$-kal nött a civil szervezetek, és duplájára emelkedett a gazdaságfejlesztési szervezetek sikeres projektjeinek aránya.

2. ÁBRA

A projektgazdák jogi forma szerinti megoszlása

(Distribution of Project Owners According to Legal Status)

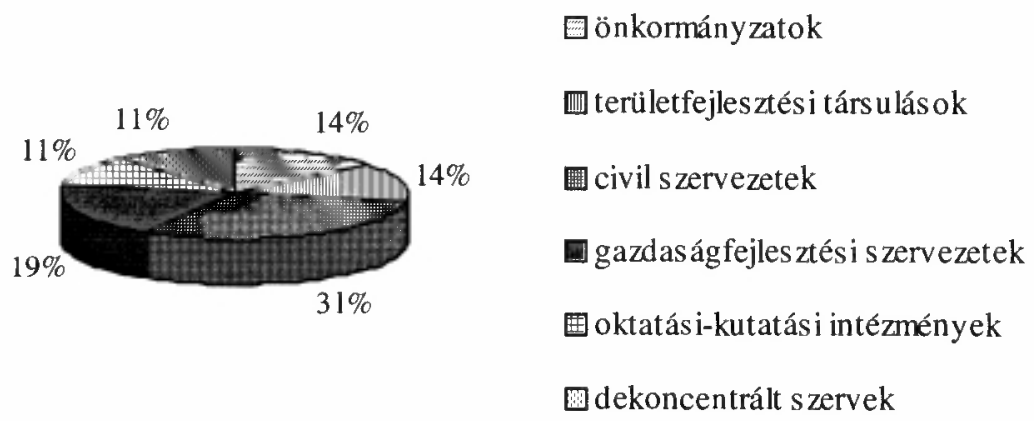

Forrás: VÁTI TFI Nyugat-dunántúli Regionális Képviselet.

A projektek nagyságrendje többségében a beruházási elemet nem tartalmazó projektekre elnyerhető 50 ezer eurós támogatási összeghez igazodott (3. ábra): a teljes projektköltség az esetek több mint felében (53\%) 40 ezer és 77 ezer euró közé esett. 6 projekt költségvetése nem érte el a 40 ezer eurót, a maradék 11-é viszont a 
110 ezret is meghaladta. A legnagyobb szabású projektek kerékpárút építéshez kapcsolódtak, amelyek a maximális 300 ezer eurós támogatás igénybevétele mellett 425, illetve 433 ezer eurós teljes beruházás értéket képviseltek.

\section{3. ÁBRA}

A projektek eloszlása a teljes projektköltség alapján

(Distribution of Projects by the Total Project Expenses)

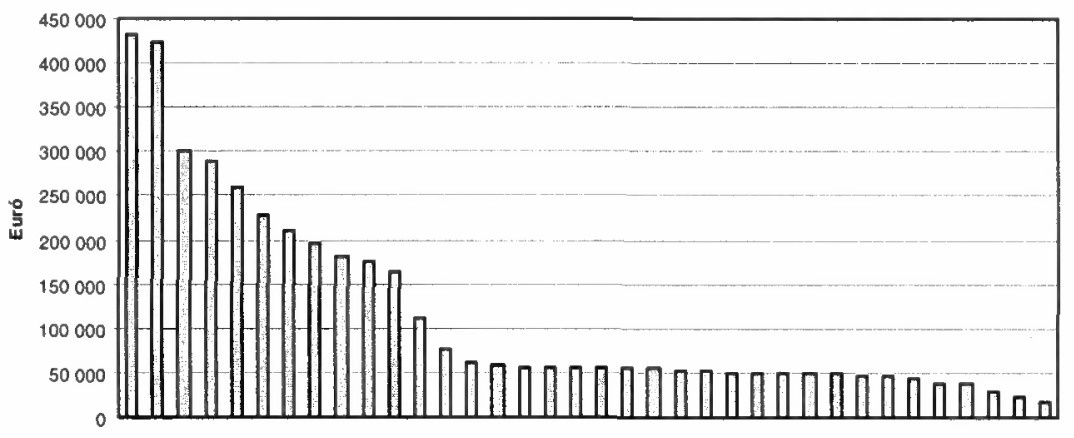

Forrás: HU0015-03 program támogatási szerződések.

A nyertes pályázó szervezetek székhelyének földrajzi megoszlása nem teljesen egyenletes. Amint azt a 4. ábra is mutatja, a gesztorok közel fele Vas megyei, amely a sikeres vasi pályázók további erősödését jelzi a régión belül. Zala tartja közel egyharmados részarányát a sikeres pályázatok összességében, míg GyőrMoson-Sopron részesedése közel 30\%-ról 24\%-ra esett vissza. Emellett lényeges az is, hogy a nagyobb projektméretek lehetősége a pénzügyileg erösebb szervezeteknek kedvez. Így a sikeres pályázatok jelentős koncentrációja tapasztalható a nagyobb település javára. A projektek pontosan fele a megyeszékhelyeken valósult meg: 10 Szombathelyen, 4-4 Györben illetve Zalaegerszegen.

\section{4. ÁBRA}

A projektek megyék szerinti megoszlása

(Distribution of Projects by Counties)

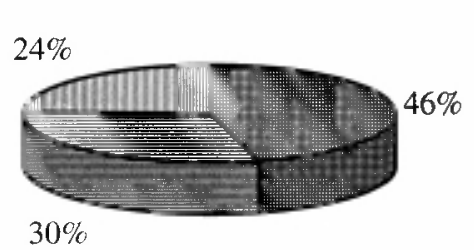

Vas

굴 Zala

凹 Györ-M.-S.

Forrás: VÁTI TFI Nyugat-dunántúli Regionális Képviselet. 


\section{Relevancia}

Az Magyarország-Ausztria Phare CBC programok átfogó célja, hogy az osztrákmagyar határrégió integrációja gazdasági, társadalmi, kulturális téren növekedjen. Ezen belül a határon átnyúló intézményi struktúrák és hálózatok elnevezésủ prioritás célja: a belső potenciálok határon átnyúló mobilizációja, a határon átnyúló együttmüködési struktúrák hatékony fejlesztése és megvalósítása, széleskörü elfogadottság és részvétel a határ menti kapcsolatokban. A 2000. évi Kisprojekt Alap a határrégió integrációját, az együttmüködési struktúrák fejlesztését úgy kívănja elérni, hogy határon átnyúló együttmüködések megerősítését és újabb együttműködési kapcsolatok létrehozását célozza meg az alábbi területeken: regionális tervezés és fejlesztés, gazdaságfejlesztés és együttmúködés, ideértve a turizmust is, emberi erőforrások fejlesztése, környezet- és természetvédelem. Az elöbbiek tükrében a 2000. évi Kisprojekt Alap célja releváns az Magyarország-Ausztria Phare CBC Program céljával és ezen belül az intézményi struktúrák és hálózatok elnevezésü prioritással.

A határrégió erősségei, lehetőségei jó kiindulópontot jelentenek a 2000. évi Kisprojekt Alap céljainak megvalósítására a már meglévő és az újonnan alakuló határon átnyúló együttmüködések erösítésére és intézményesítésére. A támogatási eszközei valós lehetőséget adnak rurális, elmaradottabb térségek számára is a fejlesztési források elnyerésére, ezzel csökkentve a regionális különbségeket. A 2000. évi Kisprojekt Alap olyan térségekben, illetve szervezeteknél indított el fejlesztési folyamatokat, amelyek eddig nem, vagy nehezen tudtak más forrásokhoz hozzájutni. Ugyanakkor a 2000-es Kisprojekt Alapból pályázó projektek mintegy fele a megyeszékhelyeken, vagy környékén valósult meg. Ez várható volt, hiszen támogatási források többségét az erösebb anyagi és humán kapacitással rendelkező térségek képesek felhasználni.

A saját erő arányának megszabása, a természetbeni hozzájárulás elfogadása segítheti a csekély szabad forrással rendelkezö szervezeteket. A nyertes pályázók háromnegyede élt a természetbeni forrás felhasználásának lehetőségével. Hat szervezet a teljes önrészt természetbeni hozzájárulásból biztosította. Az építési komponenst is tartalmazó projektek esetében a saját erő részaránya $25 \%$ volt, amelyet kizárólag készpénzben biztosíthatott a kedvezményezett. Összesen a projektek egy tizede, 3 projekt tartalmazott építési komponenst (is). A 2000. évi Kisprojekt Alap céljai összességében illeszkednek a határrégió és ezen belül a Nyugat-dunántúli régió fejlesztési igényeihez.

A 2000. évi Kisprojekt Alap szempontjából három, területileg döntően ugyanerre fókuszáló területfejlesztési dokumentum tekinthető meghatározónak:

- A Magyarország-Ausztria Interreg IIIA - Phare CBC Közös Programozási Dokumentum 2000-2006;

- A Nyugat-dunántúli régió területfejlesztési stratégiája 2000-2006;

- West/Nyugat Pannónia Eurégió Jövöképe. 
Az első két dokumentum közel azonos időszakban készült. A programkészítöket tekintve, egyes szereplők személyi átfedése miatt erős ezen dokumentumok összhangja. A Nyugat-dunántúli régió 2000-2006-os programidőszakra - 1999 és 2001 között - készített területfejlesztési stratégiája egy közép-európai szinten versenyképes régió jövőképét vetíti elöre. Ennek megvalósulását alapvetően az emberi erőforrások és az innovációs környezet fejlesztésén keresztull kívánja elérni. Ugyanakkor hangsúlyt helyez a természeti és környezeti egyensúly fenntartására és a régión belüli területi egyenlőtlenségek kezelésére is. A stratégiai célok elérése annál hatékonyabb, minél jobban kialakul a megvalósítás során egyfajta regionális tudatosság és regionális identitás. Ebben kulcsszerepe van a programon belül a „Régióépítés” c. prioritásnak, amelyben önálló intézkedésként jelenik meg a határ menti együttmúködés „Kézfogás” címen. Ennek az intézkedésnek az akcióterületei között kiemelt szerepet kap az Ausztria-Magyarország Interreg IIIA - Phare CBC program. Mivel a régióstratégia egyik fontos inputja volt a 2000-2006-os programidőszakra szóló közös programdokumentum, ez önmagában is biztosítja a folyamatos összhangot az egyes évek Phare CBC pályázati kiírásai és a regionális stratégia között.

2002-2003 folyamán elkészült a programterület magyar oldalát teljes egészében, az osztrák oldalon pedig Burgenlandot magába foglaló West/Nyugat Pannónia Eurégió jövőképe is. A dokumentum alapjaiban támaszkodik mind a Nyugatdunántúli régió területfejlesztési stratégiájára, mind Burgenland 2000-2006-os programidőszakra szóló regionális operatív programjára és az ezekkel összhangban készült közös programozási dokumentumra. Ezek együttes hatásaként a Phare CBC-s és az eurégiós célkitüzések összhangban vannak.

A project fiche-ben leírt közvetlen cél egyértelmüen megfogalmazódott a 2000. évi Kisprojekt Alap pályázati felhívásában, biztosítva ezzel annak lehetőségét, hogy a projektek célkitúzései is megfeleljenek a Kisprojekt Alap, s így a MagyarországAusztria Interreg IIIA - Phare CBC program célkitüzésének. Egy program célkitüzését a benne megvalósuló projektek átfogó, hosszú távú célkitüzéseinek tükrözniük kell. A 2000. évi Kisprojekt Alap esetében - a logikai keretmátrixok felülvizsgálata és átdolgozása után ${ }^{7}$ - a projektek átfogó célkitủzéseinek $80 \%$-a egyértelmúen illeszkedik a Kisprojekt Alap célkitüzéséhez. A maradék $20 \%$ esetében túl általánosra sikeredett az átfogó célkitüzés megfogalmazása. Ez esetben többnyire egyszerüen a „határ menti egyưttmüködéshez való hozzájárulást” fogalmazták meg átfogó célként.

A projektek közvetlen céljai az alábbi kategóriákba sorolhatóak:

- Közös kultúrkincs ápolása, fejlesztése, felkutatása

- Vállalkozások együttmúködésének elősegítése, beszállítói hálózat létrehozása

- Közös, föleg turisztikai termék fejlesztése, kialakítása

- Európai uniós ismeretek, modellek adaptálása, know-how átvétel, tapasztalatcserék

- Közös problémákon, megoldásokon való gondolkodás, közös fejlesztések előkészítése

- Civil, kutató szervezetek közötti együttmüködés alapjainak megteremtése, hatékonyságának fejlesztése, hálózatépítése. 
A projektszinten a kedvezményezettek $74 \%$-a úgy látja, hogy teljes mértékben sikerült elérnie a kitűzött célját. A $26 \%$-uk úgy érzi, hogy csak részben teljesült a projekt célja.

\section{Koherencia}

A program tervezése a Kisprojekt Alap szokásos tervezési metodikáját követte annak ellenére, hogy az eredetileg felhasználásra szánt támogatási keret is az elöző Kisprojekt Alap négyszerese volt. Menet közben ez a bövebb támogatási keret is közel megduplázódott. A támogatási maximum emelése 300 ezer euróra, és az építési komponens beágyazása a rendszerbe lehetővé tette a korábbinál nagyobb költségvetésủ projektek megvalósítását. A projektleírás szövegezése azonban nem követte a kitágult lehetőségeket, és továbbra is csak a viszonylag kisebb támogatási igényü, a közvetlen emberek közötti kapcsolatok segítését tüzte célul. Elörevetítette nagyszámú új projektgazda megjelenését, akik számára problémát jelenthet a Phare szabályokat alkalmazó projektmenedzsment, eljárási szabályok biztosítása. Ugyanakkor nem érzékelte akadályozó tényezőként a programmenedzsment szükös kapacitását a jelen Kisprojekt Alappal kapcsolatban, és az egyre több párhuzamosan futó Phare CBC programból adódóan megsokszorozódó feladatot.

Releváns döntés volt a támogatás felső határának 300 ezer euróig történő növelése, és az építési komponens lehetővé tétele. Az első elem egyfajta felkészülési lehetöséget biztosított az Interreg IIIA programban szokásos projektméret menedzselésére mind a projektgazdák, mind a programmenedzsment számára. Az építési komponens pedig elösegítette, hogy a korábbiakhoz képest drasztikusan növekedjék az átlagos projektméret. Ez pedig kezelhető szinten tarthatta a várható és a nyertes pályázatok számát. Az egyéb feladatnövekedést nem tekintve (pl. bỏvülö tender minőségbiztosítás változó PRAG szabályozás mellett) az 1999. évi Kisprojekt Alappal közel megegyezỏ számú projekt indult el a jelen felhívás eredményeként.

A tervezés során rendelkezésre álló 18 hónapos futamidő az építési komponenst is tartalmazó projektek számára is elegendőnek látszott. Az értékelési eljárás, a nyertes projektek kiválasztásának időbeni elhúzódása azonban a normál kisprojekt alap 10-12 hónapos futamidejére csökkentette a lehetöségeket. A pályázati döntés idöszakában még csupán az elökészítés szakaszában lévö építési projektek számára szükösnek is bizonyult ez az időkeret. Továbbra sem tette lehetővé a rendelkezésre álló futamidỏ osztrák partnerrel indítandó tükörprojektek megvalósítását. Az osztrák partner 3-4 éves átfutási idejü projektekkel indul az Interreg IIIA projektben, amelynek magyar oldali megvalósításához háromszor kellene pályázni.

A programmenedzsment szervezetrendszere minden megyében müködtet képviseletet. Ez segíti a programmenedzserek gyorsabb, közvetlenebb elérését területileg. Nem követi ugyanakkor a szervezeten belüli humáneröforrás-eloszlás az egyes megyékben érvényesülö projektsürüséget. Ez jelenleg Vas megyében a legerősebb, de hagyományosan Zala megyei volt a kedvezményezettek többsége. Ennek tükré- 
ben mind a szombathelyi, mind a zalaegerszegi képviselet a szükségesnél lényegesen kevesebb munkatárssal indult a program megvalósításának.

A 2000. évi Kisprojekt Alap keretében nem volt kötelező a logikai keretmátrix összeállítása, mégis a kedvezményezettek döntő többsége megpróbálta elkészíteni, illetve elkészíttetni. A projektek logikai mátrixában a tevékenységek és az eredmények általában koherensek, a várt eredmények azonban többségében a projekt kimeneteinek megnevezésére korlátozódnak, vagy nagyon áttételes, a projekthez nem közvetlenül kapcsolódó eredményt jelölnek. A projektek céljai azonban már kevésbé mondhatók koherensnek az eredményekkel. Ennek többségében az az oka, hogy a projektek közvetlen céljai nem elég konkrétak, nem kötödnek közvetlenül a projekthez, így azokat a meghatározott eredményekkel, illetve a projektek természeténél fogva (kis támogatási összegủ és hatású) nem lehet elérmi. A célok nem elég fókuszáltak, mennyiségileg is túl sok mindent szeretnének elérni egy-egy projekttel.

\section{Hatékonyság}

A VÁTI TFI Nyugat-dunántúli Regionális Képviselet helyi irodái összesen 9 fövel vettek részt az induló Kisprojekt Alap, illetve Phare CBC Program munkájában. Párhuzamosan folynak a következő Kisprojekt Alapokra és a 2 millió eurós nagyprojekteket felváltó „Támogatási Konstrukcióra” (Grant Scheme) történő előkészületek (pályázati felhívás kidolgozása, meghirdetése, a pályázati szakaszban információs napok tartása, írásban és szóban feltett kérdések megválaszolása, a pályázatok érkeztetése, az értékelési eljárás lefolytatása, nyertesek és nem nyertesek kiértesítése, szerződések elökészítése). Így a program futamideje alatt előfordult, hogy több mint 200 projekt megvalósításának nyomon kísérése zajlott egy időben a nyugatdunántúli képviseleteken. Ez programmenedzserenként kb. 30 projektet jelent.

A szombathelyi és a zalaegerszegi iroda munkatársai a magyar-osztrák program mellett a magyar-szlovén program projektjeit is kezelték. Számukra a magyarosztrák 2000. évi Kisprojekt Alap nagyjából kapacitásuk 40\%-át kötötte le. A soproni iroda munkatársai döntően a a magyar-osztrák relációval foglalkoztak, így idejük kb. háromnegyedét fordították a 2000. évi Kisprojekt Alap lebonyolítására.

Programszinten a változó háttérfeltételek egy éves csúszást eredményeztek a pályázati felhívás kiírásában. A pályázatok értékelési eljárása, a projektek kiválasztása és jóváhagyása, majd a szerződések megkötése további féléves csúszást eredményezett. A 10-12 hónapra olvadt projektmegvalósítási futamidő a programmenedzsment számára kezelhető volt, igaz a dokumentumok tanulmányozásán, egyeztetésén alapuló feladatok az utolsó három hónapra sürüsödtek be. A menedzsment jelentős sikereként értékelhetö, hogy az időzavarba került építési projektek esetében sikerült a programmegvalósítás záró határidejét meghosszabbítani a szükséges futamidővel.

Projektszinten a projektek egy részénél újra kellett tervezni az időtáblát, hogy a pályázatban lehetséges másfél éves időkeretet az új helyzethez igazítsák. A megvalósítás idejének kétharmadánál a kedvezményezettek több mint fele számolt be jelentős csúszásról. 
Lados Mihály: Programértékelés a 2000. évi Magyarország-Ausztria Phare CBC Kisprojekt Alap példáján. - Tér és Társadalom, 19. 2005. 2. 101-126. p.

Ez döntöen két okra vezethetỏ vissza:

- Az egyes komponensek megvalósítási idejének hibás tervezése.

- A tendereljárások önmagában is hosszú átfutási ideje nagyobb értékű felhívások esetében az alkalmazandó eljárás miatt. Számos esetben azonban csak a második vagy a harmadik eljárás volt sikeres.

A program- és projektmegvalósítás értékelése kiemelt figyelmet szentelt a legkisebb költség elve érvényesülésének. Ez alapvetỏen a szerződött és a megvalósított projektköltségvetés, a tervezett és a megvalósított tevékenységek, valamint a tevékenységek megvalósítását segító tendereljárások tanulmányozásával végezhető el. A program jelenlegi szakaszában a támogatások 70\%-os lekötöttsége elfogadható szintet képvisel, hiszen a zárás közelébe jutott csúszó projektek az összes támogatás közel egynegyedét kötik le.

Csak a támogatásokat tekintve a pénzügyi teljesítés 94\%-os. A fel nem használt támogatások kicsi hányada származik két-három kisösszegủ ( 1000 euró alatti) nem megvalósult tevékenységböl, és egy-egy, szintén a program egészéhez viszonyítva marginális összegű, nem elszámolható költségtételből (pl. köztisztviselő számára nem kifizethető betervezett személyi kifizetés). Lényegesen fontosabb a tendereljárások hatása a tervezetthez képest kisebb költségek alakulásában. A teljes projektköltségvetéseket tekintve 5\%-kal kevesebbe kerültek a tendereljárás keretében kiválasztott szállítóval megvalósított szolgáltatások, beszerzések (3. táblázat).

\section{TÁBLÁZAT}

A projektek költséghatékonysága tendertípusonként

(Cost Effectiveness of Projects by Type of Tenders)

\begin{tabular}{lcrrrrrr}
\hline \multirow{2}{*}{$\begin{array}{c}\text { A tender } \\
\text { típusa }\end{array}$} & $\begin{array}{c}\text { Pro- } \\
\text { jek- } \\
\text { tek }\end{array}$ & $\begin{array}{c}\text { Ten- } \\
\text { derek }\end{array}$ & Támogatás & $\begin{array}{c}\text { Összes } \\
\text { forrás }\end{array}$ & $\begin{array}{c}\text { Ajánlatok } \\
\text { összege }\end{array}$ & Arány & Különbség \\
\cline { 2 - 8 } & \multicolumn{2}{c}{ száma $(d b)$} & \multicolumn{1}{c}{$($ EUR $)$} & $($ EUR $)$ & \multicolumn{1}{c}{$($ EUR $)$} & $(\%)$ & $($ EUR $)$ \\
\hline SER0 & 13 & 40 & 23208,82 & 23825,13 & 23688,27 & 99,43 & 136,86 \\
SER1 & 20 & 50 & 131005,72 & 140383,96 & 131910,78 & 93,96 & 8473,18 \\
SER2 & 14 & 21 & 691480,00 & 705109,00 & 665006,00 & 94,31 & 40103,00 \\
SUP0 & 3 & 4 & 2572,00 & 2572,00 & 2564,90 & 99,72 & 7,10 \\
SUP1 & 7 & 10 & 28535,00 & 28879,00 & 29292,21 & 101,43 & $-413,21$ \\
SUP2 & 8 & 9 & 119254,00 & 121750,00 & 105182,00 & 86,39 & 16568,00 \\
WOR1 & 1 & 1 & 144106,00 & 162650,00 & 168614,61 & 103,67 & $-5964,61$ \\
\hline Összesen & 24 & 135 & 1140161,54 & 1185169,09 & 1126258,77 & 95,03 & 58910,32 \\
\hline
\end{tabular}

1 Összes forrás = Támogatás + Saját forrás + Partnerek hozzájárulása

Forrás: Kedvezményezettek zárójelentései alapján saját számítás.

A tendereljárás alkalmazása különösen a kicsi (SER1) és közepes (SER2) méretű szolgáltatások esetében bizonyult hatékonynak. A kisebb keretösszegü (SUPI) beszerzések és az építési tenderek esetében a tervezés és a megvalósítás közötti 
több mint egy éves időkülönbség a tervezett ár fölötti ajánlatokat hozott. A különbözetet a kedvezményezettek saját forrásból pótolták.

A Phare CBC program alapja a határ menti partnerek együttmúködése. A partnerségi viszonyokat tekintve közepesen erősnek minősíthetö a külföldi partnerek részvétele a projektek előkészitésében, megvalósításában. Az együttmüködés szélesebb területen való megvalósulása a tükörprojektek esetében valószínüsíthetö, amikor a közösen megfogalmazott cél elérése érdekében a határ két oldalán közel párhuzamosan történik a tevékenységek megvalósítása úgy, hogy mindkét fél részesül támogatási forrásból. Az Interreg IIIA és a Phare CBC eltérỏ eljárásrendje és ütemezése miatt mindössze egy tükörprojektet regisztrálhatunk a 2000. évi Kisprojekt Alap nyertes pályázatai között. Sokkal jellemzőbbek a közös részvételü rendezvények, know-how átvételek és az osztrák oldalon megvalósított tanulmányutak, amelyek szintén biztosítják az egyes projektek határon átnyúló hatását.

\section{Hatásosság}

A program hatásossága két szempontból ítélhetỏ meg. Egyfelöl a programmenedzsment müködése alapján, másfelöl annak tükrében, hogy a program és a projektek kimeneti oldalán megvalósult tevékenységek milyen mértékben járultak hozzá a program célkitüzéseinek megvalósításához.

A programmenedzsment hozzájárulását a célok megvalósulásához négy szinten vizsgáltuk:

- A pályázati időszakban;

- A pályăzatok beadásától a szerződéskötésig terjedő időszakban;

- A megvalósítás időszakában, valamint

- A monitoring tevékenység során.

A pályázati időszakban újsághirdetés, interjúk, megyei szintű információs napok, telefonos és internetes válaszadás biztosították a kedvezményezettek tájokoztatását és tajjékozódását a 2000. évi Kisprojekt Alap céljáról, lehetőségeiről, a pályázati ủrlapok kitöltéséröl, a pályázati célokról, az elismerhetö költségekröl, a pályázat eljárásrendjéről. A beadott 98 pályázat a lényegesen magasabb támogatási keret ellenére is jó eredménynek tekinthetö. Figyelembe kell ugyanis venni, hogy a pályázható támogatás maximális összege a hatszorosára emelkedett. A magasabb összegủ projekt lehetősége szükíti a potenciális pályázók körét. Ráadásul jelen Kisprojekttel szinte egy időben - egy hónap eltolódással - dolgoztak a projektgazdák a 2000. évi Magyarország-Szlovénia Phare CBC Kisprojekt Alap pályázatán is. Ez a felhívás a kedvezményezett térség kétharmadát szintén érintette. A felkészítés hatásosságát mutatja, hogy mindössze hat pályázat érkezett be késve. Ugyanakkor a pályázatok mintegy $20 \%$-a vérzett el az alapvető megfelelőségi vizsgálatok során.

A pályázat beérkezésétől induló időszak sokrétủ feladatot rótt a programmenedzsmentre a pályázatok érkeztetésétỏl, az alapvető megfelelöségi vizsgálaton, az értékelési szakértők kiválasztásán és felkészítésén, az êrtékelési eljárás lebonyolításán, a 
Delegációval történő egyeztetésén át, a szerződések elökészítéséig és a nyertes pályázók előzetes felkészítéséig. A kapacitáskorlátok és egy „vis major” eset ebben a szakaszban a program mintegy féléves csúszását okozta. A felkészítés során a résztvevők egy része első pályázóként a Phare $\mathrm{CBC}$ lebonyolítási rendszeréről kaphatott átfogó képet, és egy dossziéban összefoglalva megfelelő muníciót a további munkához. A kedvezményezettek egy másik része pedig az eljárásrendben bekövetkezett változásokat ismerhette meg. A szerződéskötést a Kincstárhoz tartozó intézmények esetében a számlanyitás késleltette.

A projektmegvalósítás során a programmenedzserek alapvető feladata a projektek ütemszerủ haladásának a figyelemmel kísérése, a támogatásból megvalósuló tenderek ajánlati dokumentációjának minőségbiztosítása volt. Mind a jelentések, mind a tenderek elökészítésének időszakában szinte napi telefonos és e-mailes kapcsolatban voltak a kedvezményezettekkel. A hatásosságot jól érzékelteti, hogy viszonylag kevés megismételt tendereljárásra volt szuikség a program teljes futamideje alatt. Erre az időszakra esett az egynapos fórum megrendezése is, amely a zárójelentésekkel kapcsolatos teendőkön túl kiscsoportos keretek között a projektmegvalósítással kapcsolatos nehézségeket is tárgyalta.

Összességében a VÁTI TFI nyugat-dunántúli képviseleteinek munkáját a kedvezményezettek pozitívan értékelték (4. táblázat). A projektmenedzserek $62 \%$-a a programmenedzsert, $21 \%$ a partnert, $8 \%$ egyéb szervezetet nevezett meg abban a tekintetben, hogy kitöl kapta a legtöbb segítséget a projekt megvalósítása során. Mindössze $9 \%$ ítélte meg úgy, hogy senki nem segítette a munkáját. A megkérdezettek kiemelték a kedvezményezettekkel való kapcsolattartás folyamatosságát, a programmenedzserek munkájának támogató jellegét és a partnerek hozzáállását. Az információk tartalmával a kedvezményezettek elégedettek voltak annak ellenére, hogy az eljárásrend, elszámolások változásai és egy-egy általánosan felmerülő probléma az átlagosnál több erőfeszítést igényelt. A projektmegvalósításban kevésbé jărtasak voltak kritikusabbak az információk megadásának sebességének és a kapott információk tartalmának megítélésében.

\section{TÁBLÁZAT}

A VÁTI TFI kirendeltségei által nyújtott segitséggel kapcsolatos elégedettség megítélése (\%) (Judgement of Satisfaction Regarding to Giving Assistance by Sub-offices of VÁTI TFI [\%])

\begin{tabular}{lccc}
\hline & Elégedett & $\begin{array}{c}\text { Részben } \\
\text { elégedett }\end{array}$ & Elégedetlen \\
\hline Konkrét segítségnyújtás & 88,8 & 8.4 & 2,8 \\
Segítségnyújtás rendszeressége & 86,1 & 11,1 & 2,8 \\
Elérhetőség (amikor kellett) & 86,1 & 13,9 & 0,0 \\
Információnyújtás tartalma & 75,0 & 25,0 & 0,0 \\
Információnyújtás sebessége & 63,9 & 16,7 & 19,4 \\
\hline
\end{tabular}

Forrás: BMGE TKK kérdöíves felmérése a nyertes pályázókkal (2003 június-augusztus).

A jelentős késéssel beérkező elörehaladási jelentések nehézkessé teszik a program közben végrahajtandó monitoringot. Ebben az esetben mind a célok megvalósulá- 
sáról, mind a támogatások lehívásának állásáról csak hiányos, töredékes információkkal bír a projektmenedzsment. Valójában jelen Kisprojekt Alap esetében csak a 2003, október-novemberi időszakban elkészített zárójelentések tartalmazzák mindazon információkat, amely alapján az egyes projektek és a program egészének az értékelése elkészíthető. A teljes monitoringot még így is csak 2004 közepén, a félévnyi haladékot kapott projektek zárójelentéseinek elkészítését követően tud készíteni/készíttetni a programmenedzsment.

A program és projekt szintủ kimenetek megvalósítását a tervezés során elkészített logikai keretmátrix alapján lehet megítélni, az értékelés eredményeként elkészíthető ún. logikai modell segítségével.

A logikai modell tartalmazza a programban létrejött outputokat, az eredményeket, valamint a hatásokat, megkülönböztetve az intézményi és a társadalmi-gazdasági hatásokat. A modell alkotóelemei közötti kapcsolatokat, és azok erősségét nyilak jelölik. A kész logikai modell alkalmasan ábrázolja azt az utat, ahogyan a program outputjai a hatásokhoz vezetnek. Az is jól megjeleníthetö, hogy melyik outputok és eredmények voltak meghatározóak, és hogy melyek a program kapcsán megvalósult leglényegesebb hatások. Végül az elkészült logikai modellt össze lehet hasonlítani a logikai kerettáblával, ahol a kitủzött célkitủzések megvalósulását az elért hatások igazolhatják, bizonyítva a program sikerességét. A 2000. évi Kisprojekt Alap logikai modelljében az outputokat, valószínüsíthető eredményeket, valamint tervezett hatásokat tudunk ábrázolni.

Az outputok tekintetében a leggyakrabban - a projektek közel felénél - megvalósult végeredmény konferenciák, szakmai fórumok, kulturális találkozók, alkotótáborok szervezése. Ezek között találunk több száz főt megmozgató rendezvényeket, de olyat is, amely egy-egy szükebb szakmai kör számára valósított meg fontos eseményt.

A projektek $40 \%$-ánál fontos elemként volt valamilyen kiadvány, marketing anyag, publikáció megjelentetése. A széles nyilvánosság felé történỏ látványos megjelenés, mint output, azért is kiemelendő, mert egyúttal a Phare CBC program ismertségéhez, elfogadottságához is számottevően hozzájárul. Ez az arány kicsit kevésnek tünik annak tükrében, hogy minden projekttel szemben elvárás volt, hogy biztosítson nyilvánosságot a projektnek. Ez valószínúleg így is történt, de nem minden esetben került be a zárójelentés output mutatói közé.

A projektek többségének fö outputja valamilyen tudás, készség, tapasztalat átadása. Az ilyen jellegủ projektek alaptípusa a képzés, oktatás, tanfolyam, amelytől azonban leginkább csak a módszer tekintetében tér el a szakmai tanulmányút. A legtöbb képzési projekt esetében fontos - külön megjelölt - outputot képeznek az elkészített tananyagok, képzési jegyzetek, kiadványok.

Az eredményeket vizsgálva a legfontosabbnak a többé-kevésbé speciális ismeretek, tudás, készség, illetve tapasztalatok bövülése tekinthető valamely meghatározott célcsoport körében. Az ilyen jellegủ eredmények értelemszerủen föként a képzési valamint tanulmányút projektekhez kapcsolhatók.

A fentinél általánosabb értelemben vett információk terjedése, a határtérség specifikumaival kapcsolatos tájékozottság növekedése szintén a projektek nagy számának 
egyik, illetve legfőbb eredménye volt. Ezt a célt leginkább a különféle kiadványok, marketinganyagok elkészítését magukban foglaló projektek segítették. A turisztikai kínálat bővüléséhez, a szolgáltatások minőségének javulásához - a termékfejlesztést kiegészítve, illetve meglévő termék hatékonyságának növelésével - szintén jelentős mértékben járultak hozzá az ilyen jellegü projektek.

A projektek többségénél megállapítható, hogy a programban való részvétel elösegítette a kedvezményezetteknél a projektmegvalósítási készség fejlódését. Ezen kívül sok projekt hozzájárult a határ ausztriai oldalán tapasztalható minőségi - vagy „EU-s” - szemlélet, valamint egyfajta közös szakmai nyelvezet elterjedéséhez. Ezt a célt fơként a különbözö konferenciák, szakmai és kulturális találkozók segítették elő. Ezek az általános eredmények nagyban elősegíthetik a jövőbeni határon átnyúló együttmüködések kialakulását és sikerességét.

A projektek értékelése nyomán megállapítható, hogy a program során létrejött legfontosabb hatások a következők:

- Fenntartható fejlódés elösegítése.

- Felkészülés az európai uniós csatlakozásra. Ez a hatás (többé-kevésbé) minden olyan projekt esetében bekövetkezett, amelynek keretében valamilyen, az EU-csatlakozás tükrében különösen fontos tudás, információ vagy készség került átadásra (képzési projektek).

- Vállalkozások versenyképességének javulása. Itt szintén fontos megemlíteni a képzési projekteket, tanulmányutakat, amelyek egy-egy szakmához tartozó vállalkozók, szakemberek számára adtak fontos új ismereteket. Emellett a külső megjelenést elösegítő PR anyagok, honlapok elkészítése is elösegítette ennek a hatásnak az érvényesülését.

- Kulturális és szelíd-, ökoturizmus fellendiulése. Ezt a hatást segítette egyrészt a kiadványok, marketinganyagok megjelentetése, másrészt pedig az ezeken a területeken történt minőségi termékfejlesztést tartalmazó projektek.

\section{Fenntarthatóság ${ }^{8}$}

A kedvezményezettek $42 \%$-a akkor is megvalósította volna valamilyen formában a projektjét, ha nem nyert volna támogatást. A projektekben létrejövő tevékenységekre meglátásuk szerint szükség volt, ezért mindenképpen részben vagy egészben megvalósították volna. A kedvezményezettek megítélése szerint a Phare CBC támogatás hiányában sokkal lassabban, vagy egy későbbi időpontban, esetleg más forrást keresve, vagy csak egy részét tudták volna megvalósítani a 2000. évi Kisprojekt Alapból támogatott projektnek. A kedvezményezettek 58\%-a elsősorban anyagi források hiányában nem vágott volna bele a projekt megvalósításába, illetve csak olyan kis részét tudta volna megvalósítani, amely elmarad a Phare CBC támogatásból megvalósult projektek céljaihoz, eredményeihez képest. 
A kedvezményezettek $48 \%$-a szerint más - minisztériumi, régiós forrásra is tudtak volna pályázni a 2000. évi Kisprojekt Alapban támogatott projektekkel, de az több szempontból is más eredményt hozott volna:

- A hazai forrásból megvalósított projekteknek valószínüsíthetően sokkal kisebb határon átnyúló hatása lett volna.

- Kisebb szervezetek úgy látják, hogy hazai forrásra nem tudtak volna sikerrel pályázni, mert országos szinten sokkal erősebb (anyagi és emberi) erőforrással rendelkező szervezeteknek jutott volna a támogatás.

- A hazai források nem lettek volna elégségesek ahhoz, hogy a projektet így egészében meg lehessen valósítani.

- Más forrás esetén esetleg nagyobb sajáterö-hozzájárulással kellett volna számolni, amelyet már nem tudott volna biztosítani a szervezet.

A projekthez, vagy annak kiteljesedéséhez a Kisprojekt Alap támogatásán kívül a projektek $40 \%$-a esetében kapcsolódtak más források. Ezek egy része más támogatási forrásból nyert pályázat, amely kiegészíti, teljessé teszi a projekt eredményeit. Abban az esetben, ha a gesztorszervezet partnere minisztérium, a projektmegvalósítás során felmerülő kiegészítő költségek (pl. plusz adminisztrációs kapacitás) finanszírozására többnyire keresnek megoldásokat. Az osztrák partnerek néhány esetben kerestek lehetőséget plusz források bevonására, vagy bizonyos tevékenységekért nem kértek ellenszolgáltatást.

Fontos kérdés a projektek fenntarthatósága szempontjából az, hogy a projekt indukál-e további pályázatot, alapja lesz-e további fejlesztésnek. Mindössze a projektek egyötödénél nem vetődött fel, vagy nagyon bizonytalanok abban, hogy a megvalósítás után folytatódik-e az eredmények továbbvitele valamilyen más projekt keretében. A kedvezményezettek egynegyede hazai forrásból, 55\%-a pedig további Phare $\mathrm{CBC}$ forrás bevonásával szeretné teljesebbé tenni a projektje eredményeit.

Többen már jelen program megvalósítása időszakában benyújtottak Phare CBC nagyprojekt pályázatot, vagy tervezték azt. Voltak, akik az osztrák partnerrel tükörprojekt megvalósítását tervezték, de néhányan a projektet más határ menti térség bevonásával képzelték el (szlovén, horvát, szlovák). Legtöbben a projektek keretében létrejött szolgáltatásokat, termékeket szeretnék továbbfejleszteni, kiegészíteni, vagy megismételni. A kedvezményezettek fele konkrétan megnevezte milyen témában kíván, illetve már elkezdett további fejlesztéseket megvalósítani. Az új projektek esetében a kedvezményezettek több mint fele a mostani partnereivel pályázna és körülbelül egyharmada a jelenlegi partnereken túl, bővítené az együittmüködési kört.

A kedvezményezettek az alábbi tényezőkben látják projektjeik hosszú távú fenntarthatóságát:

- A projekt eredménye beépuilt a szervezet szolgáltatásába, kínálatába

- Fenntartható trendek elterjedése: természeti értékek megörzése, megújuló energiaforrás hasznosítása, szelíd turizmus növekedése a térségben

- Határon átnyúló kapcsolatok megerősödése 
Lados Mihály: Programértékelés a 2000. évi Magyarország-Ausztria Phare CBC Kisprojekt Alap példáján. - Tér és Társadalom, 19. 2005. 2. 101-126. p.

- Partnerszervezetek közös érdekeltsége, további közös projektek tervezése

- További pályázatok, fejlesztések szükségesek

- Szervezeti rendszer, hálózat kialakulása az eredmény továbbvitelére

- Igény, szükséglet az eredmény iránt a célcsoport részéről

A kedvezményezettek 40\%-a szerint teljesen, 10\%-a szerint részben rendelkezésre állnak ezek a tényezők a hosszú távú fenntarthatóság biztosítására. Rövidebb távon az eredmények a kedvezményezettek szerint fenntarthatóak, mivel tartós igény mutatkozik rájuk. A fenntartáshoz szükséges források rendelkezésre állnak, vagy várhatóan rendelkezésre fognak állni az interjúválaszok alapján. Többen további pályázatok útján látják a finanszírozás biztosítását, néhány projekt a szolgáltatások bevételeiből fedezi az eredmények fenntartását.

A zárójelentések elemzésébỏl kitủnik, hogy a projektek egyharmadánál elsősorban a megvalósitó szervezet szakmai színvonala, ismertsége, tevékenységi terủlete, valamint szervezeti, illetve pénzügyi háttere jelenti a legföbb biztosítékot a fenntarthatóságra. Fontos szempont, hogy a szervezeten belül szilárd szándék mutatkozzon a projekt folytatására, fenntartására. A projektek egyötödénél inkább a kialakult kapcsolatok - kétoldalú partnerségek, valamint hálózatok - intenzitása és kiterjedtsége a fenntarthatóság legfontosabb tényezöje. Minden hetedik projekt esetében újabb nyertes pályázat révén, illetve saját forrásból történik a projekt folytatása, kiterjesztése.

További tényezök, amelyek több projekt esetében is hozzájárulnak a fenntarthatósághoz:

- a projekt keretében olyan kézzelfogható termék jött létre, amely ỏnmagában biztosítja a kitüzött célok továbbvitelét (térkép, tábla stb.);

- komplexitás, egymásra épủlö, egymást erösítő elemek;

- földrajzi kiterjesztés szándéka és lehetösége;

- innovatív jelleg;

- a projekt tartalma: újabb, nagyobb projekt elökészítése.

\section{Partnerség}

A Kisprojekt Alapok esetében kiemelt szempont, hogy az osztrák és magyar partnerek közỏtt hogyan valósul meg az együttmúködés. A VÁTI TFI által készített "Phare CBC projektek értékelése 1995-1999" címü tanulmány lehetóséget ad arra, hogy összehasonlító értékelést is végezzünk (5. táblázat). A 2000. évi Kisprojekt Alap esetében volt elöször a projektkiválasztás alapvetỏ követelménye a pályázók számára külföldi partner bevonása, részvétele a projektmegvalósításba. Ezért különösen érdekes lehet annak vizsgálata, hogy látható-e ennek az intézkedésnek az eredménye a projektek határon átnyúló hatásainak tekintetében.

A szervezetek többsége csupán egy kủlföldi partnerrel tart erős kapcsolatot és/vagy néhány szervezettel van esetenként egyuittmüködése, laza kapcsolata. Ez arra utal, hogy számos szervezet kifejezetten a jelen Kisprojekt Alap keretei között keresett elöször partnert az osztrák oldalon. A szervezetek többsége ugyanakkor 
kiterjedt hazai partnerhálóval rendelkezik. A projektek egyharmadánál (35\%) a kedvezményezettnek mind a hazai, mind a külföldi partnerrel volt már közös pályázata, és igen jelentős azon szervezeték száma (40\%), ahol a 2000. évi Kisprojekt Alap keretében megvalósított projekt az első közös együttmüködés a hazai és a külföldi partnerrel egyaránt. A kedvezményezettek 41\%-a igényelne (1995-99-es felmérés 76\%-ával szemben) segítséget megfelelö külföldi partnerszervezet felkutatása, megkeresése terén az együttmüködés kiépítéséhez. Különösen az önkormányzatok és azok társulásai, civil szervezetek, valamint azok, akiknek ez az első közös projektje a külföldi partnerszervezettel. Ehhez a VÁTI Kht. honlapján a Gyakran Feltett Kérdések szekcióban voltak címek, a Nyugat-dunántúli Regionális Fejlesztési Ügynökség pedig kérés alapján részletesen foglalkozott egyéni megkeresésekkel.

\section{TÁBLÁZAT}

A partnerkapcsolatok erössége (\%)

(Strength of Partner Relations [\%])

\begin{tabular}{lccc}
\hline \multicolumn{1}{c}{ Kapcsolati típusok } & $\begin{array}{c}1995- \\
1999 \\
\text { külföldi }\end{array}$ & $\begin{array}{c}2000- \\
2006 \\
\text { külföldi }\end{array}$ & $\begin{array}{c}2000- \\
2006 \\
\text { hazai }\end{array}$ \\
\hline $\begin{array}{l}\text { Nincsenek kapcsolataik partnerszervezetekkel } \\
\begin{array}{l}\text { Egy partnerszervezettel van meghatározó, } \\
\text { erős kapcsolat }\end{array}\end{array}$ & 13,4 & - & 10,0 \\
$\begin{array}{l}\text { Néhány szervezettel (max. 4) van kapcsola- } \\
\text { tuk, de ezek nem túlzottan erősek }\end{array}$ & 37,3 & 20,6 & 13,3 \\
$\begin{array}{l}\text { Néhány partnerszervezettel (max. 4) van meg- } \\
\text { határozó együttmüködés (közös gondolkodás) }\end{array}$ & 21,3 & 20,6 & 6,7 \\
$\begin{array}{l}\text { Kiterjedt kapcsolati hálóval rendelkeznek } \\
\text { (min. 5), ezek közül néhány szervezettel kifeje- }\end{array}$ & 9,3 & 14,7 & 36,7 \\
$\begin{array}{l}\text { zetten szoros az együttmüködés, míg a többjvel } \\
\text { inkább csak formális }\end{array}$ & & & \\
$\begin{array}{l}\text { Kiterjedt kapcsolati hálóval rendelkeznek, } \\
\text { ezek közül több (min. 5) partnerszervezettel } \\
\text { van kifejezetten szoros kapcsolat }\end{array}$ & 5,3 & 11,7 & 26,6 \\
\hline \begin{tabular}{l} 
Összesen \\
\hline
\end{tabular} & 100,0 & 100,0 & 100,0 \\
\hline
\end{tabular}

Forrás: BMGE TKK kérdôives felmérése a nyertes pályázókkal (2003. június-augusztus).

Az együttmúködések erősségének igazi mércéje az, hogy milyen szinten vonja be a partnert a kedvezményezett a projekttervezés, megvalósítás, fenntartás különböző fázisaiba (6. táblázat). Az Interreg IIIA - Phare CBC 2000-2006-os Programok vizsgálata során ötfokozatú skálát használnak az együttmüködés erősségének mérésére. Ezt a skálát alkalmazta a BMGE TKK vizsgálata is. A projektmenedzserek öt területen végzett önértékelésével egy $1-5$-ig ${ }^{9}$ terjedö skálán értékelték a külföldi partner bevonásának erősségét. 
Lados Mihály: Programértékelés a 2000. évi Magyarország-Ausztria Phare CBC Kisprojekt Alap példáján. - Tér és Társadalom, 19. 2005. 2. 101-126. p.

\section{TÁBLÁZAT}

Az együittmüködés erössége a projekt egyes szakaszaiban (Strength of Cooperation in Several Phases of the Project)

\begin{tabular}{lc}
\hline \multicolumn{1}{c}{ Projekt szakaszok } & Átlagos pontszám \\
\hline Projekt tervezése során & 3,6 \\
Pályázatírás során & 2,0 \\
Projekt megvalósítása során & 4,1 \\
Projekt finanszírozásában & 1,4 \\
Projekt fenntartásában & 3,5 \\
\hline
\end{tabular}

Forrás: BMGE TKK kérdőíves felmérése a nyertes pályázókkal (2003. június-augusztus).

Összességében közepesen erősnek minősíthető a külföldi partnerek részvétele a projektek elökészítésében, megvalósításában. Az egyưttmúködés szélesebb területen való megvalósulása a tükörprojektek esetében valószínüsíthető, amikor a közösen megfogalmazott cél elérése érdekében a határ két oldalán közel párhuzamosan történik a tevékenységek megvalósítása úgy, hogy mindkét fél részesül támogatási forrásból. Az Interreg IIIA és a Phare CBC eltérỏ eljárásrendje és uitemezése miatt mindössze egy tükörprojektet regisztrálhatunk a 2000. évi Kisprojekt Alap nyertes pályázatai között ${ }^{10}$. Sokkal jellemzöbbek a közös részvételü rendezvények, knowhow átvételek és az osztrák oldalon megvalósított tanulmányutak, amelyek szintén biztosítják az egyes projektek határon átnyúló hatását.

A tervezés során az osztrák partnerek segítettek a végrehajtandó lépések felépítésében, a tevékenységi területek, tematikák meghatározásában, ötletet adtak, mintát szolgáltattak. A pályázatírás kapesán kisebb mértékben müködtek közre a külföldi szervezetek: személyes konzultációk, egyeztetések történtek, segítettek néhány melléklet kitöltésében és anyagokat biztosítottak. A projektek kivitelezése folyamán különbözó mértékủ volt a külföldi partner részvétele, szerepe. A projektek egy részénél a projekt összes kimeneteinek eredményeinek létrehozása az osztrák féllel kőzösen toörtént. A legtipikusabb formája a külföldi partnerek bevonásának a megvalósítás egy-egy szakaszában, konkrét feladat végrehajtásában mutatkozott meg, mint például az előadók biztositása, az osztrák tanulmányút megszervezése, szakértői közremüködés, külföldi együttmüködö szervezetek, célcsoportok megtalálása és velük a kapcsolattartás biztositása.

Néhány esetben tapasztalható volt, hogy a megvalósítás közepén-végén még nem volt teljesen konkrét az osztrák partner szerepe a projekt kivitelezésében. A projektek finanszírozásához alig járultak hozzá az osztrák partnerek. Előadók, szakértők bérét, a tanulmányutakkal kapcsolatos költségek egy részét fizették 3-4 projekt esetében. Pozitívabb képet mutat viszont az, hogy a projektek fenntartásában látnak a kedvezményezettek szerepet az osztrák fél részéről, amely a kapcsolatok tartásában, további közős projektek kialakításában, néhány esetben a projekt eredményének közös anyagi fenntartásában nyilvánul meg.

A kedvezményezettek $80 \%$-ának véleménye szerint a projekt céljai eléréséhez kritikusan fontos, $14 \%$ szerint fontos, és $6 \%$ szerint kis mértékben volt fontos a külföldi partnerek bevonása. Nemcsak azért mert a pályázat elöírása volt az osztrák partner 
bevonása a projektmegvalósításba, hanem mert szakmai tudásuk, tapasztalatuk nélkiilözhetetlen volt az eredmények szempontjából. Néhány kedvezményezett véleménye szerint azért is, mert a célok határon átnyúló hatások elérését túzték ki. A külfö̈ldi partner részvétele a megvalósítás során több szempontból is pozitív hatással járt:

- Új technológiák, eljárások, modellek megismerése

- Olyan tapasztalatokhoz, ismeretekhez jutás, amely más módon nem lenne lehetséges

- Kapcsolatépítés, határon átnyúló együttmüködések kialakulása

- Önbizalmat ad, ,rálátást ad az előttünk járók tevékenységére”

Az 1995-99-es felméréshez képest nem változott az együttmủködést nehezítő tényezök megítélésének sorrendje (7. táblázat). A partnerszervezet hozzáállását a 2000. évi Kisprojekt Alap támogatottjai egyáltalán nem tapasztalták nehezítỏ tényezőnek. Ezt aż is alátámasztja, hogy a külföldi partnerrel történő együttmúködéssel kapcsolatban szinte semmilyen negatív jelenségrỏl nem számoltak be a kedvezményezettek. Egy esetben meghiúsult a tükörprojekt az osztrák oldalon, két esetben érdektelenségröl, passzivitásról panaszkodtak, melynek oka valószínủleg az eltérö célokból adódott, és egy esetben a túl sok egyeztetés okozott nehézségeket.

\section{TÁBLÁZAT}

Az együttmüködést nehezítö tényezők megoszlása (Distribution of Cooperation Impedimental Factors)

\begin{tabular}{|c|c|}
\hline Tényezők & Megoszlás (\%) \\
\hline Nyelvi nehézségek & 27 \\
\hline Eltérö fejlettségből adódó eltérỏ célok & 27 \\
\hline Eltérő jogi környezet & 19 \\
\hline Pályázati támogatások eltérỏ szabályozása & 15 \\
\hline Partnerszervezet nem megfelelő hozzáállása & 0 \\
\hline Egyéb felsorolás & 12 \\
\hline Összesen & 100 \\
\hline
\end{tabular}

Forrás: BMGE TKK kérdőíves felmérése a nyertes pályázókkal (2003. június-augusztus).

Összességében a „gazdaságfejlesztés és együttműködés, ideértve a turizmus” intézkedési területen valósult meg legkevésbé mind az öt területen a külföldi partnerek bevonása a projektmenedzserek megítélése alapján. Jellegénél fogva ez az a terület, ahol esetleg versenytársként tekinthetik egymást a felek és ennek feloldása, együttmüködések kialakítása komoly többletmunkával, szemléletformálással jár. Az osztrák partnerekről egyöntetủen az a kedvezményezettek véleménye, hogy megbízhatóak. Sem a külföldi partnerek megtalálása, sem a velük való együttmüködés nem jelentkezett komoly problémaként. A nyelvtudásbeli hiányosságok azonban továbbra is akadályozó tényezője a partneri kapcsolatok elmélyítésének. A projektek többségénél az osztrák fél szerepe tudás, tapasztalat átadásában, a modellek szolgáltatásában merül ki. Egyre több azon projektek száma, amely a tapasztalatok cseréjéről szól, az eredmények létrehozása közösen történik, valódi közös termék, szolgáltatás kialakítása felé mutat. 


\section{Összegzés}

A Phare CBC Kisprojekt Alap nagy potenciállal bír a határ menti kapcsolatok elösegítésében. Jól bizonyítja ezt, hogy Magyarország 2004. május 1-i uniós csatlakozásáig meghirdetett 9 Kisprojekt Alap pályázati felhívásra több mint ezer pályázat érkezett be, és több mint 300 projekt kapott támogatást elképzeléseinek megvalósítására. A 2000. évi Magyarország-Ausztria Kisprojekt Alap több tekintetben is sajátosnak tekinthető. Egyrészt ez a kírás alkalmazta kiválasztási kritériumként a határon átnyúló partnerség meglétét a projektben, másrészt a korábbinál lényegesen magasabb volt az elérhető támogatás összege. Söt kivételes esetként a projekt építési komponenst is tartalmazhatott, ami addig nem és a késöbbiekben sem volt lehetséges kisprojektek esetében. Ez lehetőséget teremtett a nagyprojekteket felváltó, az Interreg projekt méreteket jobban közelítő támogatási konstrukció (grant scheme) típusú rendszer program szintủ elökészítésére és projekt szintủ menedzselésére.

A benyújtott közel száz projekt jelentős eröfeszítéseket kívánt meg a pályázóktól a partneri kapcsolatok kialakítását tekintve. Elkezdödött a ,partneri nyilatkozat aláirása" típusú kapcsolat átalakulása. Az osztrák partnerek a pályázatok készítését a partnerségi nyilatkozaton túl konzultációkkal segítették, míg az egyes projektek megvalósításában a szerepük jellemzỏen előadók biztosítása, az osztrák tanulmányút megszervezése, szakértöi közremüködés, külföldi együttmüködő szervezetek, célcsoportok megtalálása és velük a kapcsolattartás biztosítása volt. Az együttmüködés magasabb szintjét jelző tükörprojekt azonban csupán egy volt a nyertes pályázatok között.

A legjobb szándékok szerint sem könnyủ tükör- és közös projektek megvalósítása az osztrák partnerekkel. Ez elsősorban az Interreg IIIA és a Phare CBC program eltéró szabályozási rendjéből fakad. Míg az Interreg IIIA program a teljes programidőszakra szóló szabályozással bír, addig a Phare CBC éves program bázison működik. Minden egyes éves keretre önálló felhívás készül, amelynek elökészítése, a pályázati idöszak, a pályázatok értékelése és a szerződéskötés jellemzően több időt vesz igénybe, mint amennyi a megvalósításhoz a kedvezményezetteknek rendelkezésre áll. A Kisprojekt Alapból támogatott projektek jellemző futamideje így 12 hónap, míg a szomszédok 2-4 éves átfutásúra tervezik Interreg IIIA projektjeiket. Komoly tükörvagy közös projekt megvalósításához a magyar partnernek többször, és minden alkalommal sikeresen kell pályáznia. Ez csak kis számban fordulhat elö.

Az egyensúlytalanságot erösíti, hogy az Interreg IIIA projektek jellemzöen közepes méretűek, ez elnyerhető összeg néhány százezer eurótól a másfél-két millió eurós nagyságrendig terjed. A magyar partnerek viszont nem haladhatják meg az 50 ezer eurós Phare CBC Kisprojekt Alap támogatási határt. Annyi saját forrásuk pedig nincsen, hogy az osztrák partner forrásszintjéig kipótolják a támogatást. Az osztrák oldal nagyobb abszorpciós képességét az is segíti, hogy maguk a megfelelö pénzügyi háttérrel rendelkező tartományok és a tartományi szervezetek biztosítják a projektek saját (50\%-os) forrását. Magyar oldalon viszont az ennek a közép szintnek megfelelö megye és régió sem rendelkezik olyan saját forrásbázissal, amellyel nagyobb léptékü Phare CBC projekteket felvállalna. 
A nehézségek ellenére a Phare CBC Kisprojekt Alap a határ menti kapcsolatok fejlesztésén túl, jelentősen hozzájárult az EU-támogatási rendszer alkalmazásának tanulási folyamatához is. İgy a pályázatíróként megjelenỏ mintegy 800 , és a megvalósításban résztvevő több mint 200 szervezet jelentös tapasztalatokat gyưjtött az EU-s pályázatok kidolgozásában, menedzselésében és nem utolsó sorban a pályázati felhívásonként változó szabályozási környezethez való alkalmazkodásban.

A Strukturális Alapok pályázati rendszerének 2004. év eleji indulásával valamelyest csökkenhet az érdeklődés a Phare CBC-t 2004-től felváltó MagyarországAusztria Interreg IIIA program iránt. A források felhasználása kevéssé okozhat problémát, hiszen a 2004-2006 közötti idöszak rendelkezésre álló átlagos évi forrása egyharmada a megelőzö évek Phare CBC keretének. Így nem várható a kapcsolatok látvånyos bövülése, ugyanakkor minden korábbinál erőteljesebbé válhat a partnerség érvényesülése.

Ennek hatékonyságát jelentősen rontja, hogy az érintett osztrák tartomảnyok gyakorlatilag 2004-ig már felhasználták, vagy lekötötték a hét éves időszakra szolgáló Interreg IIIA forrásaikat. Így gyakorlatilag nem, vagy nagyon kevés számú tükörvagy közös projekt valósulhat meg ebben a csonka programidöszakban. A kiegyenlített partneri viszonyok kialakulása a 2007-2013-as programidőszakra marad.

\section{Jegyzetek}

${ }^{1}$ Az 1998. évi Magyarország-Ausztria Phare CBC program keretét a kísérleti magyar-román és magyar-szlovăk Phare CBC programra csoportosították át.

2 Phare CBC Kisprojekt Alap típusú programok a Nyugat-dunántúli régióban 1995-1999. VÁTI TFI, 2002.

${ }^{3}$ A területfejlesztés és kisvállalkozás-fejlesztés témaköreiben a teljes Phare kedvezményezett közép- és kelet-európai térségre a bírminghami székhelyü West Middlands Enterprise Ltd. látta el a keretszerzödỏ szervezet feladatait az 1994-1999-es programidőszakban.

4 A végrehajtás szervezete a természetes személyi változásokon túl csak nevében változott az elözỏ időszakhoz képest, 1999 óta stabil, kismértékben növekvő humán kapacitással.

${ }^{5}$ A pályázati kiírásban rendelkezésre álló 1.860 ezer euró 20 projekt megvalósítását tette lehetỏvé. Az Irányító Hatóság dőntése alapján a HU0015 program nagyprojektjeiből megmaradt források további 17 projekt támogatását tették lehetỏvé.

${ }^{6}$ A pályázati kiírás 500 ezer eurót biztosított a klasszikus kisprojektek számára, amelyek csak beszerzési és szolgáltatási komponenst tartalmazhattak 5-50 ezer eurós értékben. A keret nagyobb hănyada 1,36 millió euró - olyan 50-500 ezer eurós projektek támogatását kedvezményezte, amelyek építési komponenst is tartalmazhattak. Az építést is végző projektek esetében a saját forrás szükséges mértéke az általános $10 \%$-kal szemben $25 \%$ volt, amelyet a kedvezményezett csak készpénzben teljesíthetett.

${ }^{7}$ A 2000. évi Kisprojekt Alap pályázat beadásakor nem volt kötelezỏ a logikai keretmátrix beadása. A program félidejében, Vasszécsényben megtartott felkészítés alapján a pályázók egy része elkészítette vagy újra írta a projektjére vonatkozó logikai kerettáblát. Összességében a projektgazdák éppen fele nyújtott be új vagy megújított táblázatot.

${ }^{8}$ A fejezet döntôen a BMGE TKK által készített kérdőíves felmérés és az egyes projektek zárójelentéseinek elemzésére támaszkodik.

9 1- nem vontuk be, 3 kis mértékben, 5- teljes mértékben bevontuk a külföldi partnert.

${ }^{10}$ A győri székhelyü INNONET Kht. által megvalósított „KOOPERNET - Együttmüködés versenyben” c. projektje a kismartoni Technologiezentrum "Start Smart Chance Ungarn” c. Interreg IIIA projekt tükörprojektjeként indult. 


\section{Irodalom}

A magyarországi Phare CBC Programeredményei 1995-2001. (2002) VÁTI TFI, Budapest.

A Nyugat-dunántúli régió területfejlesztési koncepciója. (1998) MTA RKK NYUTI, Györ.

A Nyugat-dunántúli régió teruleteffejlesztési programja 2000-2006. (2001) MTA RKK NYUTI, Györ.

Austria-Hungary Interreg IIIA - Phare CBC Joint Programming Document 2000-2006. (2000) EC, Brussels.

Kisprojekt Alap HU.00.15.03 Pályázati Útmutató. (2000) VÁTI TFI, Budapest.

Lados, M. (2000) Cross-border Cooperation in Hungary. MTA RKK NYUTI, Györ.

Lados, M. (2000) Zusammenarbeit über die Grenzen: der sanfte Druck der EU. - RAUM - Österreichische Zeitschrift für Raumplanung und Regionalpolitik. 37. März. 18-21. o.

Magyarország-Ausztria Phare CBC Program Kisprojekt Alap (HU001503) - Értékelö tanulmány. (2004) VÁTI TFI - BMGE TKK., Budapest.

Gordos, H. M. (2003) Monitoring Report No. M/HU/CBC/03063 - Hungary-Austria CBC 2000 HU0015. NARD, Budapest.

Gordos, H. M. (2003) Monitoring Report No. M/HU/CBC/03066 - Hungary-Austria CBC 2001 HUO 108. NARD, Budapest.

Gordos, H. M. (2003) Monitoring Report No. M/HU/CBC/03071 - 2002 Cross-Border Co-operation Programme Hungary-Austria (2002/000-317). NARD, Budapest.

Phare CBC Kisprojekt Alap típusú programok a Nyugat-dunántúli régióban 1995-1999. (2002) VÁTI TFI, Budapest.

Small Projects Fund HU.00.15.03 Standard Summary Project Fiche. VÁTI TFI, Budapest.

\section{PROGRAM EVALUATION - CASE OF HUNGARY-AUSTRIA PHARE CBC SMALL PROJECT FUND 2000}

\section{LADOS MIHÁLY}

One of the engine to initiate and develop cross-border co-operation in the border region of Hungary and Austria is that the European Union pays particular attention to border regions as it has usually been lagging behind regions. For the member states the Interreg, for the nonmember states along the EU border the Phare CBC programme supports the implementation of cross-border initiatives. The increasing dense, and depth, additionally vary of cooperations may move this process from a neighbour position divided by the state boundary towards an integrated (border) region. The success and popularity of the program within the European Union is signed by the new proposal for the forthcoming 2007-2013 programming period of the EU regarding cross-border co-operation. In future the Community Initiatives will be rejected from the financial tools of European Regional Policy. However, CBC issues will move to Structural Funds objectives. It is required to stop for a moment and evaluate that how each program promotes the process of the integration process of border regions. This study makes some efforts to get this process through the ex-post type evaluation of the Hungary-Austria Phare CBC Small Project Fund 2002. The key components of the research are the evaluation of relevance, coherence, efficiency, effectiveness and sustainability both on program and project level. The study pays particular attention to cross-border partnership of the implemented projects. 